EXPERIMENTAL STUDY

\title{
Sensitivity to exogenous GH and reversibility of the reduced IGF-I gene expression in aging rats
}

\author{
Beatriz Velasco, Lucinda Cacicedo ${ }^{1}$, Elvira Melian, Gumersindo Fernández-Vázquez and Franco Sánchez-Franco \\ Servicio de Endocrinología, Hospital Carlos III-C.I.C., Instituto de Salud Carlos III, Sinesio Delgado 10-12, Madrid 28029 and ${ }^{1}$ Servicio de \\ Endocrinología, Hospital Ramón y Cajal, Ctra. Colmenar Km 9.0, Madrid 28034, Spain \\ (Correspondence should be addressed to Franco Sánchez-Franco; Email: fsanchez@hciii.insalud.es)
}

\begin{abstract}
Background: IGF-I gene expression and IGF-I plasma concentration decline with age. A decreased sensitivity to $\mathrm{GH}$ has been suggested to be a contributory mechanism to this, in addition to attenuated GH secretion.

Objective: This study focuses on the sensitivity to exogenous GH and the reversibility of the reduced IGF-I gene expression in aging male rats.

Design: Three groups of male Wistar rats aged 3 months (young adult), 11 months (middle-aged) and 27 months (old), received recombinant human $\mathrm{GH}$ (rhGH) $(150 \mu \mathrm{g} / 12 \mathrm{~h} \mathrm{s.c.}$ ) for seven consecutive days.

Results: This rhGH treatment completely reversed plasma immunoreactive IGF-I (IR-IGF-I) and hepatic IGF-I mRNA levels in 11-month-old and 27-month-old animals to the levels of the young group of animals. The sensitivity in the old group (percentage of increment after the same or lower dose of rhGH per body weight) was increased for both parameters; serum IGF-I increment: $15 \%$ in 3-month-old, $42.6 \%$ in 11-month-old and $119.1 \%$ in 27 -month-old rats; and hepatic IGF-Ib mRNA increase: $45 \%$ in 3 -month-old, $27.8 \%$ in 11 -month-old and $64.3 \%$ in 27 -month-old rats. IGF binding protein-3 (IGFBP-3) mRNA level in the liver was significantly decreased in the old group and only a partial reversion occurred in this group after rhGH treatment; the percentage of increment was also higher in the old group of rats. In extrahepatic tissues IGF-I mRNA was not significantly different in the kidney and the testis of the three groups, and the rhGH treatment produced a significant and similar increase of IGF-I mRNA level in the kidney of the three groups of rats and in the testis of the 27-month-old animals. The GHr/GHBP mRNA remained unchanged in the liver and in the kidney or the testis of the three groups, and was not influenced by the rhGH treatment. Exogenous rhGH decreased pituitary GH mRNA accumulation in a more intense manner in the old group versus control of each group: young adult, $25 \%$; middle-aged, $41.2 \%$; and old rats, $55 \%$. The action of rhGH on pituitary immunoreactive GH (IR-GH) content was only significantly evident in the young group. Conclusions: These results establish that exogenous rhGH recovers the attenuated liver IGF-I gene expression and the diminished plasma IR-IGF-I in old rats to the levels of young adult animals. They also indicate that the hepatic and extrahepatic (kidney and testis) sensitivity to one established dose per weight of exogenous rhGH is not altered in old animals, or could be potentially increased in some tissues.
\end{abstract}

European Journal of Endocrinology 145 73-85

\section{Introduction}

Growth hormone (GH) secretion declines during normal aging in the human and in the rat, resulting in lower serum insulin-like growth factor I (IGF-I) levels (1-10). Many aging-related catabolic changes, including osteoporosis and muscle atrophy in the human, are in part caused by the decreased action of the GH-IGF-I axis (1-3). Patients with GH deficiency have neuropsychiatric changes (such as impaired psychological well-being, impaired emotional reaction, depression and alterations of cognitive functions) and an increased overall cardiovascular mortality $(2-5)$. Although the existence of GH deficiency syndrome in normal elderly subjects is still not generally recognized, several investigators have initiated $\mathrm{GH}$ treatment for elderly patients with relative hyposomatotropinemia, with improvements observed in all these conditions (4). GH administration to non-elderly adults and older persons increases lean body mass and reduces fat mass substantially, increases basal metabolic rate, nitrogen and phosphate retention, spinal bone density, and 
significantly decreases fasting cholesterol levels (4, $6,7)$.

GH secretion in the male rat is pulsatile in nature and is governed by an endogenous ultradian rhythm of approximately $3.3 \mathrm{~h}(8)$. In old male rats GH secretion is depressed, and this is associated with diminished pulsatile release of $\mathrm{GH}$. The amplitude and duration of the pulses decrease, but the periodicity or number of pulses appears to be similar to that present in younger animals (9). That this decline in GH secretion of aging rats is due to aging and not to weight increase associated with aging was demonstrated in previous studies from our laboratory (10).

IGF-I is highly expressed in the liver, and this tissue is a major source of plasma concentration of the hormone as has been recently confirmed in conditional knockout of mouse liver IGF-I gene using the Cre/loxP system $(11,12)$. The age-related decline in plasma IGF-I has been documented in several strains of rodents, nonhuman primates and humans, and the exploration of the mechanism responsible for the decrease in IGF-I has focused mainly on the reduction in $\mathrm{GH}$ secretion that occurs with age (13). Previous studies have provided compelling evidence that a decrease in the amplitude of GH secretory episodes is a major contributing factor in this decline of hepatic IGF-I gene expression and serum IGF-I that occurs in aging $(14,15)$.

IGF-I is a mitogenic peptide which is thought to mediate many of the growth-promoting and some metabolic effects of $\mathrm{GH}$ and this hormone has been shown to regulate the steady-state level of IGF-I mRNA in both hepatic and extrahepatic tissues (16-18). The fact that IGF-I gene is expressed in most extrahepatic tissues supports the well-established concept that IGF-I does not act exclusively in an endocrine, but also in an auto- or paracrine, manner $(19,20)$.

As IGF-I biological action is modified by IGF-binding proteins (IGFBPs), local production of IGFBPs could have a major impact on the auto/paracrine mode of IGF-I action. Locally produced IGFBPs may retain IGF-I at the site of synthesis or extract IGF-I from the circulation and thereby provide a local IGF-I reservoir (21). GH co-regulates most of the IGFBPs, mainly IGFBP-3, in parallel with the total circulating IGF-I level (22).

Tissue response to GH depends on GH concentration, the patterns of GH delivery (23), the abundance of GH receptors $(\mathrm{GHr})(24)$ and perhaps the concentration of a soluble GH binding protein (GHBP) that has been characterized in serum of humans $(25,26)$ and animals (27-29). In aging animals the decline in GH gene expression and secretion as well as the attenuation of GH pulse amplitude is considered to be a major mechanism of the decreased hepatic IGF-I gene expression and plasma immunoreactive IGF-I (IR-IGF-I) $(10,14,15)$. In favor of this hypothesis are the studies of the GHr showing an increase in specific binding sites in the liver of aging female rats (30) or a twofold increase in hepatic GHr binding sites density of aging female mice (31).

However, some studies have shown a reduction or absence of GH-induced IGF-I gene expression in the liver of aging mice compared with younger animals (31). This, together with the important increase in $\mathrm{GHr}$ binding capacity that occurs with age, suggests that the signal transduction pathway for GH might be altered in the liver or other extrahepatic tissues of aging mice. This partial resistance to GH with aging has also been shown for the liver IGF-I secretion in humans (32).

However, there are not well-established data on the sensitivity of extrahepatic tissues to GH in aging, neither in humans nor in animals, and in particular the kidney and the testis, two organs influenced by aging that express the $\mathrm{GH}$ receptor gene.

Therefore, the present study was undertaken to define whether exogenous GH administration is able to revert to normal adult level the alterations of the IGF-I/ IGFBP-3 gene expression and secretion that occur with aging in hepatic and extrahepatic tissues such as kidney and testis, and to determine the sensitivity to one established repeated dose of exogenous recombinant human GH (rhGH) in the three groups of male rats of different ages, two of them (middle-aged and old groups) with no significant difference in weight (10). Also, we tried to obtain additional information on the inhibitory action of exogenous rhGH on the pituitary as an indication of the functionality or sensitivity of the pituitary long-loop feedback regulation in aging.

\section{Materials and methods}

\section{Animals and experimental design}

Young ( 3 months), middle-aged (11 months) and old (27 months) male Wistar rats were obtained from the University of Granada (Spain) and Criffa (Charles River, Barcelona, Spain). Upon arrival at our institution, the animals were housed in a specific pathogen-free facility and maintained on a $12 \mathrm{~h}$ light:12 h darkness cycle. Water and food was available ad libitum to all animals. The maintenance and handling of the animals were performed as recommended by the NIH guidelines on the care and use of laboratory animals according to the principles expressed in the declaration of Helsinki. Six groups of ten male Wistar rats, two young adult groups (3 months old), two middle aged groups (11 months old) and two old groups (27 months old), were studied. The body weight (g, mean \pm s.E.) of animals was $361 \pm$ $5.6,713 \pm 39$ and $635 \pm 38$ for 3, 11 and 27-monthold rats respectively, with no significant difference between the 11-month-old and the 27-month-old rats. Two groups of each age were treated as follows: control group, which received vehicle, and GH-treated group, which received rhGH $150 \mu \mathrm{g} /$ every 12 h s.c. for seven consecutive days. rhGH was graciously provided by Lilly S.A. (Madrid, Spain). 
After decapitation, blood was collected and stored at $-20{ }^{\circ} \mathrm{C}$ until assayed for immunoreactive $\mathrm{GH}$ and IGF-I. For RIA determination, half pituitary was stored at $-80{ }^{\circ} \mathrm{C}$ until used. For mRNA quantitation, liver, kidney, testis and pituitary were removed under sterile conditions, rapidly frozen on dry ice and stored at $-80{ }^{\circ} \mathrm{C}$ until used.

\section{RIAs}

Serum and pituitary immunoreactive rat GH (IR-GH) concentrations were quantitated using the National Pituitary Hormone Distribution Program rat hormone kit (NIAMDD, Bethesda, MD, USA) with a sensitivity limit of $0.8 \mu \mathrm{g} / \mathrm{l}$. Serum IGF-I was measured by a commercial RIA (Nichols Institute, San Juan Capistrano, CA, USA) after acid ethanol extraction.

All the parameters were measured in serum and pituitary from individual rats, and all samples from animals used for comparison were analyzed in the same assay to avoid inter-assay variations. The intra-assay variation of GH RIA was $7 \%$.

\section{RNA probes}

IGF-I Rat IGF-I was subcloned into a pGEM-3 vector (Promega Biotech, Madison, WI, USA), and the plasmid DNA was linearized with HindIII to allow for transcription of antisense IGF-I RNAs. This antisense RNA protected a 224 base and a 376 base fragment. One fragment of $376 \mathrm{bp}$ from the rat IGF-I cDNA, containing part of the A domain, the entire $\mathrm{D}$ and $\mathrm{E}$ domains, and part of the $3^{\prime}$-untranslated region, was generated to simultaneously quantify mRNAs with (IGF-I transcript b (IGF-Ib): $376 \mathrm{bp}$ ) and without (IGF-I transcript a (IGF-Ia): $224 \mathrm{bp}$ ) the $52 \mathrm{bp}$ insert present in the $\mathrm{E}$ domain of some IGF-I mRNAs $(22,33)$.

GHr The rat GHr probe was transcribed from a 900 bp BglII fragment of a rat GHr cDNA corresponding to the region encoding the signal peptide, the extracellular domain, the transmembrane domain, and a portion of the intracellular domain (34). The rat GHr cDNA was subcloned into the vector pT7T3 (kindly provided by Dr L. Mathews). For transcription of antisense GH receptor RNAs, the plasmid DNA was linearized with BamHI, which resulted in GHr antisense RNAs 439 bases in length. This antisense RNA protected a 439 base fragment representing mRNAs that encode the $\mathrm{GHr}$ and a 298 base fragment representing mRNAs that encode the $\mathrm{GH}$ binding protein.

GH The rat GH probe was a fragment linearized with HindIII of the plasmid p-rGH-1 (35).

Cyclophilin The rat cyclophilin cDNA was a 132 bp fragment linearized with ApaI and transcribed to generate the antisense probe with SP6 polymerase following previously described methods (36).

IGFBP-3 The rat IGFBP-3 cDNA probe was subcloned in a pGEM4Z vector (Promega Biotech) and the plasmid DNA was linearized with SacI to allow for transcription of antisense mRNA. This antisense mRNA protected a $2.5 \mathrm{~kb}$ fragment (37).

\section{Ribonuclease protection assay}

Liver, kidney and testis RNA were extracted using the Chomczynski and Sacchi method (38). In the ribonuclease protection assay, total RNA from pools of three rats were hybridized overnight with approximately 600000 c.p.m. of labeled antisense rat IGF-I or GHr riboprobe at $45^{\circ} \mathrm{C}$. The hybridization solution contained $75 \%$ (vol./vol.) formamide, $80 \mathrm{mM}$ Tris-HCl, $\mathrm{pH}$ 7.6, $4 \mathrm{mM}$ EDTA, $1.6 \mathrm{~mol} / \mathrm{l} \mathrm{NaCl}$ and 0.4\% SDS. After hybridization, samples were digested using RNase A $(40 \mu \mathrm{g} / \mathrm{ml})$ and RNase $\mathrm{T} 1(2 \mu \mathrm{g} / \mathrm{ml})$ for $1 \mathrm{~h}$ at $30{ }^{\circ} \mathrm{C}$. Protected hybrids were isolated by ethanol precipitation after phenol-chloroform extraction and separated according to size on an $8 \%$ polyacrylamide $-8 \mathrm{~mol} / \mathrm{l}$ urea denaturing gel. Gels were exposed to X-ray film (Kodak, Cambridge, UK) at $-80{ }^{\circ} \mathrm{C}$ for $24-36 \mathrm{~h}$. Quantitation of the intensities of the autoradiography bands corresponding to protected hybrids was done by densitometric scanning using Adobe Photoshop 2.0 and NIH Image 1.47 programs (Macintosh). All samples were hybridized at the same time with cyclophilin to correct for the differences in gel loading.

\section{Northern analysis}

Total RNA was electrophoresed in a 1\% agarose$0.66 \mathrm{~mol} / \mathrm{l}$ formaldehyde gel, followed by electrotransfer to nylon membrane (Nytran, Shleicher \& Shuell, Keene NH, USA) and UV cross-linking (Hoefer Scientific Instrument, San Francisco, CA, USA). Membranes were prehybridized and hybridized for $24 \mathrm{~h}$ at $65^{\circ} \mathrm{C}$ and $42{ }^{\circ} \mathrm{C}$ for IGFBP-3 and $\mathrm{GH}$ probes respectively, in $50 \%$ formamide with approximately 600000 c.p.m./ml of ${ }^{32} \mathrm{P}$-uridine triphosphate $(800 \mathrm{Ci} / \mathrm{mmol})$ labeled antisense rat probe. Autodiagrams and quantitation of intensities were done as described above. Equal loading was confirmed and data was expressed as arbitrary units after correction for hybridization with cyclophilin.

\section{Statistical analysis}

All data (mean of percentages vs control group 3month-old animals) were analyzed with one-way ANOVA followed by Scheffé F-test for comparison for multiple groups within an experiment. Samples of male rats (nine animals/age group) were compared in each experiment. The difference was considered statistically significant when $P<0.05$. 


\section{Results}

\section{Serum IR-GH and IR-IGF-I}

The effect of exogenous rhGH administration on serum IR-GH and IR-IGF-I is shown in Table 1. In young and middle-aged rats, treatment with rhGH led to a significant decrease in serum IR-GH, whereas in old rats, this treatment produced no significant alterations.

Under the conditions used in this study, treatment with rhGH increased serum IR-IGF-I to the levels of the young adult group in middle-aged and old rats, although the old rats had 53\% lower levels of IGF-I than controls, supporting the idea that the liver's sensitivity to exogenous GH in old rats is not decreased.

\section{Liver IGF-I mRNA levels}

In order to determine whether the diminution of IGF-I gene expression in the liver that occurs with aging is reversible and therefore due to the decrease in GH gene expression and GH secretion, and how important is the influence of a potential altered sensitivity to GH, IGF-I mRNA levels in hepatic tissue extracts were quantitated after exogenous rhGH administration to the three groups of animals (Fig. 1).

Treatment with rhGH increased IGF-Ib transcript in all the experimental groups compared with the nontreated group of the same age: in young group $25.3 \pm$ $8.3 \%, P<0.05$; in middle-aged group $24.8 \pm 9.1 \%$, $P<0.05$; and in old rats $47.6 \pm 4.3 \%, P<0.01$; whereas IGF-Ia mRNA accumulation was only increased in old rats after the administration of exogenous rhGH $45.8 \pm 6 \%, P<0.01$. These results indicate that this treatment produces a complete reversion to the levels of young animals in the accumulation of hepatic IGF-Ib mRNAs in middleaged and old rats, and IGF-Ia transcript in old animals, the only group in which this transcript was significantly diminished. The results also suggest that the liver sensitivity in old rats, receiving the same dose per body weight as the middle-aged, is increased, since the percentage of increment is higher in the old animals.

Table 1 Serum IR-GH and serum IR-IGF-I in control and GHtreated animals of different ages $(3,11$ and 27 months). Data represent absolute values (percentage) vs 3 month group. Results are means \pm S.E. ( $n=5-6$ animals per group).

\begin{tabular}{llcc}
\hline & \multicolumn{1}{c}{$\begin{array}{c}\text { IR-GH } \\
(\% 3 \text { months })\end{array}$} & $\begin{array}{c}\text { IR-IGF-I } \\
(\% 3 \text { months })\end{array}$ \\
\hline 3 months & Control & \multicolumn{1}{c}{100} & 100 \\
& GH treated & $19.71 \pm 15.8^{\mathrm{a}}$ & $115.92 \pm 11.2$ \\
11 months & Control & $90.57 \pm 9.43$ & $82.21 \pm 3.3$ \\
& GH treated & $39.85 \pm 16.3^{\mathrm{b}}$ & $117.03 \pm 11.1^{\mathrm{c}}$ \\
& Control & $25.36 \pm 19.6^{\mathrm{a}, \mathrm{b}}$ & $47.02 \pm 2.8^{\mathrm{a}, \mathrm{b}}$ \\
& GH treated & $22.46 \pm 5.6$ & $103.03 \pm 7.4^{\mathrm{d}}$ \\
\hline
\end{tabular}

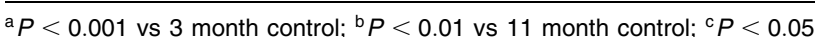
vs 11 month control; ${ }^{\mathrm{d}} P<0.001$ vs 27 month control.

\section{IGFBP-3 mRNA levels in the liver}

Due to the importance of IGFBPs on the biological action of IGF-I, and of IGFBP-3 in particular, and because this is a target gene for $\mathrm{GH}$, the $\mathrm{GH}$-induced IGFBP-3 gene expression was studied in the liver of rats of different ages. As shown in Fig. 2, the administration of exogenous rhGH produced a significant increase in IGFBP-3 mRNA levels in the three groups of animals: in the young adult group $38.1 \pm 2.3 \%, P<0.001$; in the middle-aged group $13.2 \pm 3.7 \%, P<0.05$; and in the old rats $37.5 \pm 4.2 \%, P<0.001$ versus the levels in the non-treated group of the same age. So, as happened with IGF-I, the expression of IGFBP-3 gene is additionally induced also in the presence of sufficient endogenous GH. In the group of old rats, in which IGFBP-3 mRNA was significantly diminished, the exogenous $\mathrm{GH}$ was not able to completely reverse to the levels of young adult rats the accumulation of liver IGFBP-3 mRNA, but the percentage of increment was similar to the young group and even higher than the middle-aged group that received the same dose per body weight.

\section{Kidney and testis IGF-Ia mRNA levels}

The action of GH on IGF-I gene expression in extrahepatic tissues, in particular the kidney and the testis, in relation with age has not been established. In order to clarify this, basal IGF-Ia mRNA in the kidney and in testicular tissue extracts was quantitated in the three groups of rats of different ages and after the administration of exogenous rhGH. As shown in Fig. 3, the levels of IGF-Ia mRNA in the kidney (Fig. 3a) were no different in young, middle-aged and old rats. Similar results were found when IGF-I mRNA was measured in testicular tissue extracts (Fig. $3 b$ ) of the three groups of animals.

After the administration of rhGH in the doses and route used in this study, a significant increase in the levels of IGF-Ia mRNA occurred in the kidney of the young, middle-aged and old rats: in young group $74.3 \pm 6 \%, P<0.001 ;$ middle-aged group $51.3 \pm$ $13.8 \%, P<0.01$; and in old rats $37.8 \pm 5 \%, P<$ 0.01 versus the levels in the non-treated group of the same age. In the testis, rhGH treatment produced a significant increase of the IGF-Ia mRNA accumulation only in the group of old animals. This data clearly establishes that the IGF-I gene expression in the kidney is inducible by exogenous GH at all ages studied, but in the testis was only shown in the group of old rats, and indicate that the sensitivity to $\mathrm{GH}$ in the testis of old rats is not diminished; in the kidney, data suggest a tendency to a decreased sensitivity with age.

\section{GHr/GHBP mRNA levels in the liver}

Since the biological action of GH on the target IGF-I gene in the liver must be mediated by the $\mathrm{GH}$ receptor, 


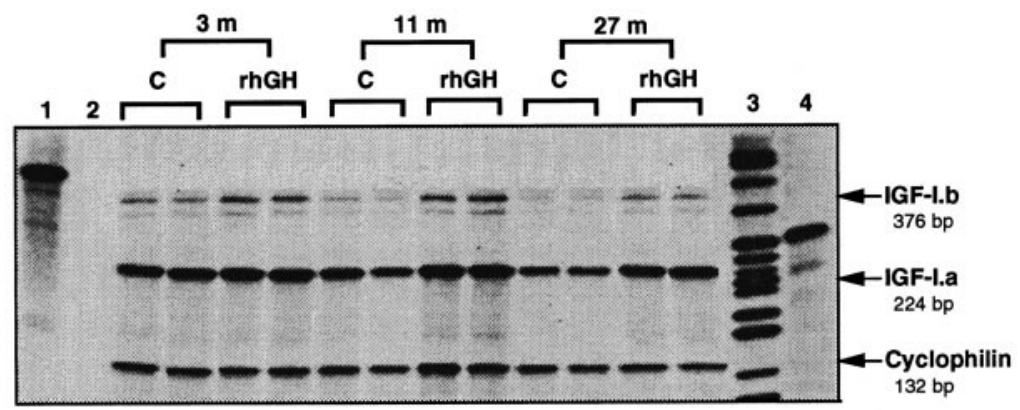

IGF-I.b

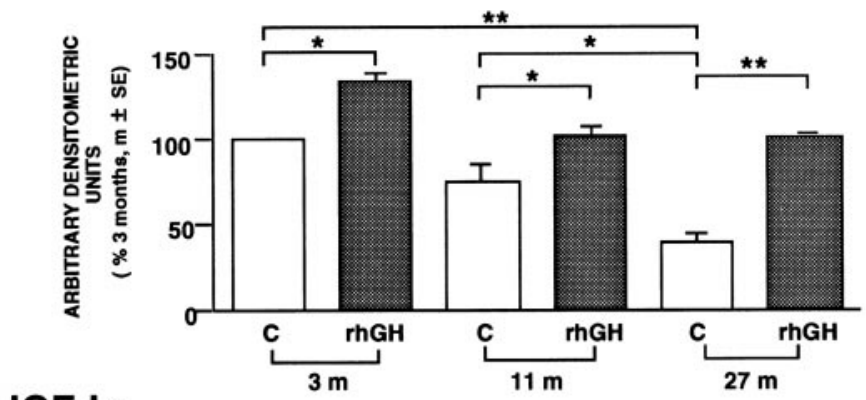

IGF-I.a

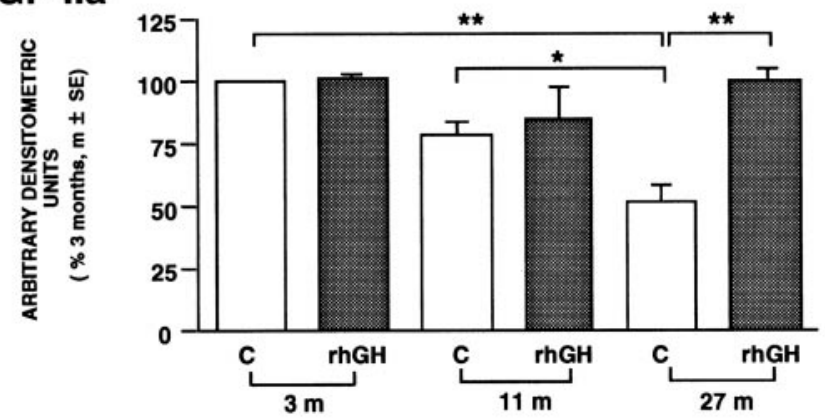

Figure 1 Liver IGF-I mRNA of young (3month-old), middle-aged (11-month-old) and old (27-month-old) rats and the effect of rhGH administration. Twenty micrograms of total liver RNA were subjected to solution hybridization/RNase protection assay using the antisense IGF-I and cyclophilin probes. The positions of each protected fragment are indicated on the right. After correction for cyclophilin levels, optical density units were adjusted so that the ratio obtained from livers of rats aged 3 months $(3 \mathrm{~m}$ ) equaled 100 . Lane 1, undigested IGF-I probe. Lane 2, IGF-I and cyclophilin probes after RNase A and T1 digestion. Lane 3 , molecular weight marker. Lane 4, undigested cyclophilin probe. Each lane represents a pool of three rats. Results are the mean \pm S.E. of three lanes. ${ }^{*} P<0.05$ and ${ }^{\star \star} P<0.01$. the expression of this gene during aging was studied. The mRNA accumulation of the two transcripts, $\mathrm{GHr}$ and GHBP, in liver extracts of the three groups of animals was no different (Fig. 4). As shown in the same figure, the administration of exogenous rhGH does not alter the levels of the two transcripts of the $\mathrm{GH}$ receptor gene in any of the three groups of different age. These data indicate that the alterations of the IGF-I gene expression that occurs with aging in the liver are mediated by modifications of the ligand $\mathrm{GH}$ and/or post-transcriptional modifications of the $\mathrm{GH}$ receptor or the receptor signaling pathways and not by transcriptional alteration of the gene.

\section{GHr/GHBP mRNA levels in the kidney}

In order to better understand the absence of alterations of IGF-I mRNA accumulation in the kidney of rats of different ages, even in the presence of the significant decrease of $\mathrm{GH}$ secretion that occurs with aging, the level of expression of the $\mathrm{GH}$ receptor gene in this tissue was studied. As shown in Fig. 5, no difference was seen in the levels of mRNA of the two transcripts of the GH receptor, GHr and GHBP, in any of the three groups of animals of different age. Again the level of the GH receptor gene expression in the kidney was not altered by the administration of exogenous rhGH to the rats of different ages.

\section{GHr/GHBP mRNA levels in the testis}

With the purpose of implementing the information related to the regulation of the IGF-I gene expression in extrahepatic tissues, the level of expression of the GH receptor gene was studied in testicular tissue of rats of different ages and the potential influence of exogenous GH examined. As shown in Fig. 6, no difference was seen in the accumulation of GHr mRNA in any of the three groups of rats of different age and no alteration was produced in these levels by the administration of exogenous rhGH. These data indicate that the induction 


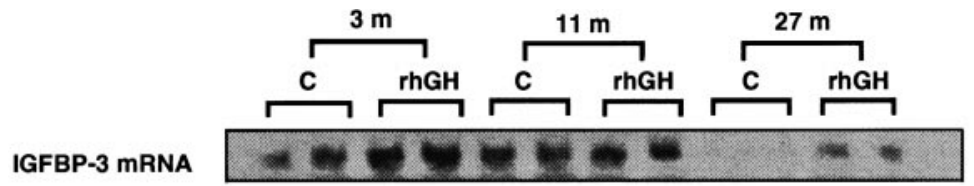

$2.5 \mathrm{~Kb}$

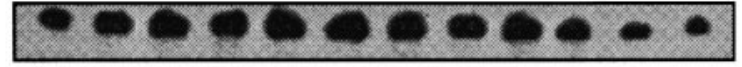

$0.8 \mathrm{~Kb}$

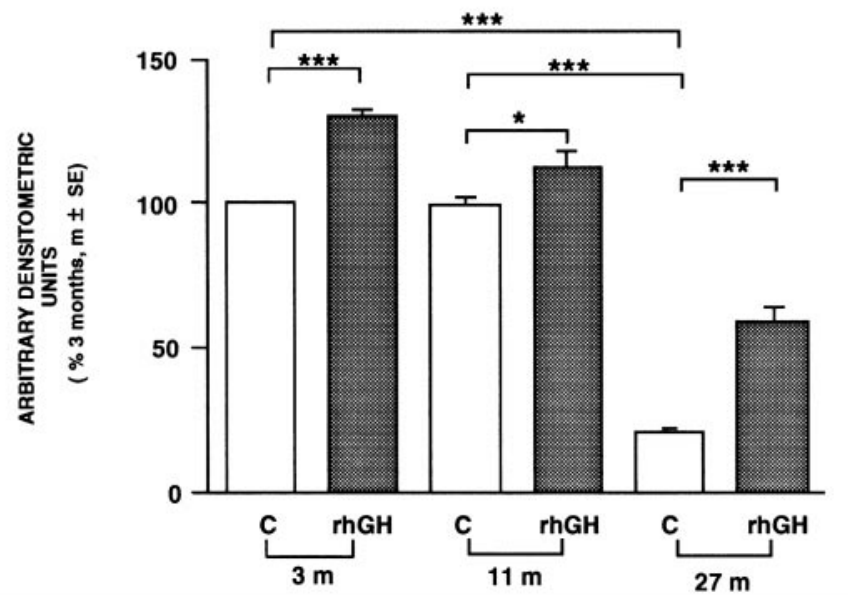

Figure 2 Liver IGFBP-3 of young (3-monthold), middle-aged (11-month-old) and old (27-month-old) rats and the effect of rhGH treatment. Twenty micrograms of total liver RNA were subjected to Northern blot using the IGFBP-3 probe. After correction for cyclophilin levels, optical density units were adjusted so that the ratio obtained from livers of rats aged 3 months $(3 \mathrm{~m})$ equaled 100. Each lane represents a pool of three rats. Results are the mean \pm S.E. of three lanes. ${ }^{*} P<0.05$ and ${ }^{* * *} P<0.001$.

of the IGF-I gene expression that occurs in the testis of old animals after treatment with rhGH is not mediated by transcriptional alterations of the $\mathrm{GH}$ receptor gene.

\section{GH gene expression in the pituitary and IR-GH content}

In order to define the sensitivity of the pituitary to exogenous $\mathrm{GH}$ in different ages, GH mRNA and IR-GH levels were studied in pituitary extracts. Northern blot analysis of pituitary GH gene expression is shown in Fig. $7 A$. After rhGH administration, GH mRNA levels in the pituitary were diminished in all the experimental groups: in the young group $25 \pm 5.2 \%, P<0.01$; in the middle-aged group $41.2 \pm 6.3 \%, P<0.001$; and in the old group $55 \pm 4.8 \%, P<0.001$, versus the non-treated rats of the same age. This suggests that exogenous $\mathrm{GH}$ decreases its own gene expression in young, middle-aged and old animals. Once more, this action is more pronounced in old rats for the same dose per body weight, suggesting an increased sensitivity in the pituitary of the old animals to exogenous GH. The effect of exogenous $\mathrm{GH}$ on pituitary IR-GH content is shown in Fig. 7B. Exogenous rhGH administration increased IR-GH pituitary content only in young rats, but these levels were not modified significantly in middle-aged and old animals, suggesting that exogenous rhGH blocks $\mathrm{GH}$ release and consequently increases its pituitary content in young rats, and this effect is not so relevant with aging.

These data indicate a similar sensitivity to the same dose of exogenous $\mathrm{GH}$ in the pituitary long-loop feedback regulation system of $\mathrm{GH}$ gene expression and secretion in aging animals, compared with middleaged or young rats.

\section{Discussion}

This study confirms that the activity of the GH-IGFI-IGFBP-3 system declines with senescence. The age-associated decreases in serum IGF-I peptide and hepatic IGF-I and IGFBP-3 mRNAs reflect the ageassociated attenuation of pituitary GH secretion (1-4, $10)$, and there is no indication of a decreased sensitivity to exogenous rhGH, at least in the dose and form of administration used in this study. The administration of pharmacological doses of exogenous $\mathrm{GH}$ in this physiological condition of relative $\mathrm{GH}$ deficiency is able to overcome this partial deficiency inducing the expression of target genes such as IGF-I and IGFBP-3 in the liver almost to the level of young adult animals. Therefore, the aging rat can be 
(a)

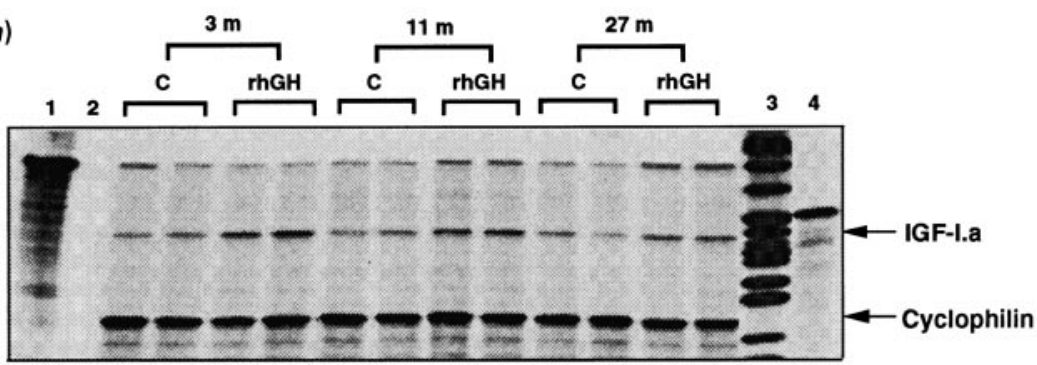

IGF-I.a

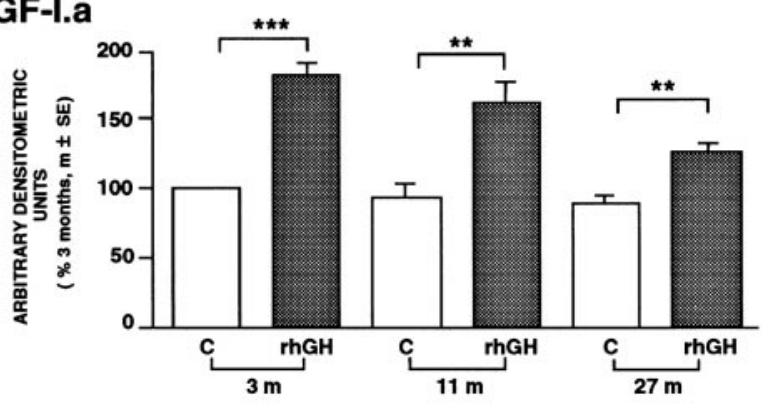

(b)

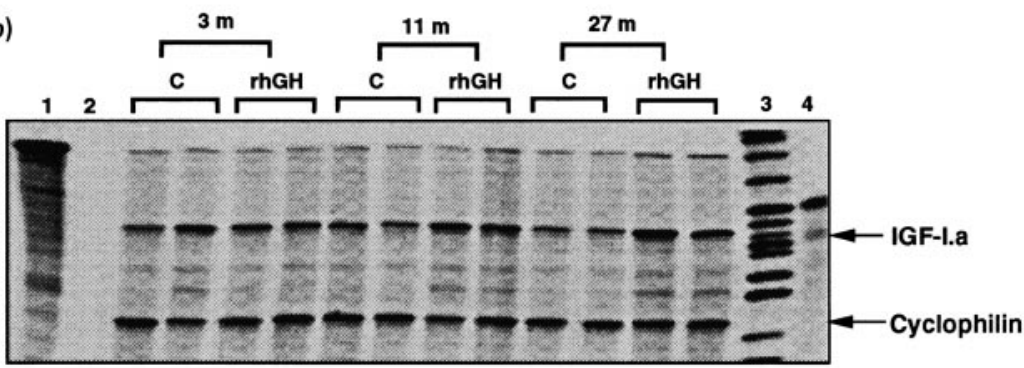

IGF-I.a

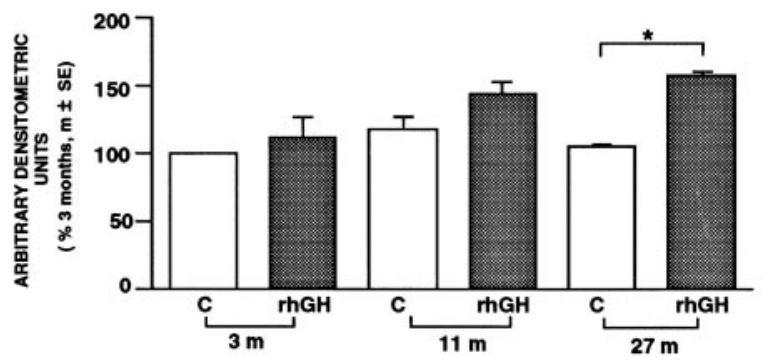

Figure 3 IGF-la mRNA in the kidney (a) and the testis $(b)$ of young (3-month-old), middleaged (11-month-old) and old (27-month-old) rats and the effect of rhGH treatment. Twenty micrograms of total kidney and testis RNA were subjected to solution hybridization/ RNase protection assay using the antisense IGF-I and cyclophilin probes. The positions of each protected fragment are indicated on the right. After correction for cyclophilin levels, optical density units were adjusted so that the ratio obtained from kidneys and testis of rats aged 3 months $(3 \mathrm{~m}$ ) equaled 100. Lane 1 , undigested IGF-I probe. Lane 2, IGF-I and cyclophilin probes after RNase A and T1 digestion. Lane 3, molecular weight marker. Lane 4, undigested cyclophilin probe. Each lane represents a pool of three rats. Results are the mean \pm s.E. of three lanes. ${ }^{*} P<0.05$, ${ }^{\star \star} P<0.01$ and ${ }^{* \star *} P<0.001$. considered a model of relative GH deficiency, not a physiological situation of $\mathrm{GH}$ resistance.

In the rat, the induction of liver IGF-I gene by exogenous $\mathrm{GH}$ has been clearly demonstrated in animals made $\mathrm{GH}$ deficient by hypophysectomy (39). However, in partially deficient rats, specific doses and frequency of $\mathrm{GH}$ administration are required to make this effect evident. In fact, it was not observed when one dose of $200 \mu \mathrm{g} /$ day was given to 24-month-old normal rats for 7 days (40). In this study we have been able to show a complete reversion of the liver IGF-I mRNA to the levels of young adult rats, by giving $150 \mu \mathrm{g}$ every $12 \mathrm{~h}$ by s.c. route for 7 days to 27 month-old normal animals. Recent studies have suggested that the signal transduction pathway for $\mathrm{GH}$ is impaired in the liver of aging rats (31) and the aging in human males is accompanied by resistance to $\mathrm{GH}$ (32), considering this peripheral tissue resistance a contributing mechanism to the attenuation of IGF-I gene expression in aging. Those studies introduced the question of sensitivity to $\mathrm{GH}$ in aging and the reversibility of the diminished plasma concentration of IGF-I and the decreased tissue function characteristic of aging animals and humans. Regarding the hepatic IGF-I gene expression, our data indicate that the sensitivity to the established dose per weight of exogenous $\mathrm{GH}$ is not affected in old animals, compared with the middle-aged group with the same weight and 


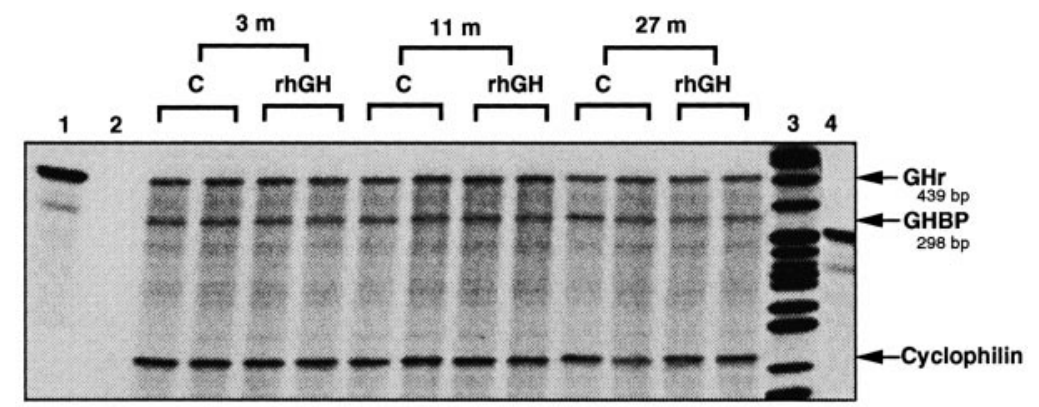

GHr
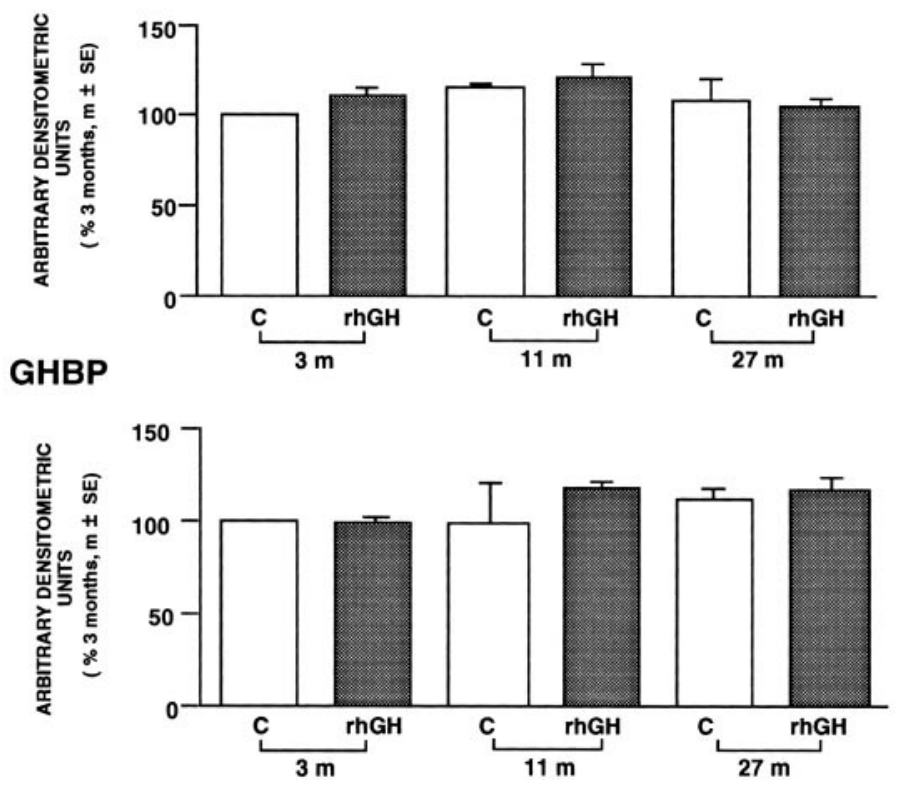

Figure $4 \mathrm{GHr}$ and GHBP mRNAs in the liver of young (3-month-old), middle-aged (11month-old) and old (27-month-old) rats and the effect of rhGH treatment. Twenty micrograms of total liver RNA were subjected to solution hybridization/RNase protection assay using the antisense $\mathrm{GHr} / \mathrm{GHBP}$ and cyclophilin probes. The positions of each protected fragment are indicated on the right. After correction for cyclophilin levels, optical density units were adjusted so that the ratio obtained from livers of rats aged 3 months $(3 \mathrm{~m})$ equaled 100 . Lane 1 , undigested IGF-I probe. Lane 2, IGF-I and cyclophilin probes after RNase A and T1 digestion. Lane 3, molecular weight marker. Lane 4, undigested cyclophilin probe. Each lane represents a pool of three rats. Results are the mean \pm S.E. of three lanes. also to the young group receiving the same dose with lower weight.

Serum IGF-I levels progressively decrease with advancing age. After rhGH treatment, serum IR-IGF-I levels do not show significant changes in the young group, whereas middle-aged and old groups, which have lower basal levels, showed a significant increase of IGF-I values. Our data is in agreement with other studies where after chronic or acute treatment, a clear increase of IGF-I levels were shown in hypophysectomized animals but not in young normal rats (41). This finding also confirms the reversibility of serum IGF-I in the old animals to the levels of young rats after exogenous rhGH, and that the hepatic sensitivity to exogenous rhGH is not decreased in old male rats.

As indicated previously by other authors $(15,42)$ and our studies (10), we confirm that hepatic IGFBP-3 gene expression diminishes with aging and that the influence of weight on these changes can be excluded. After rhGH treatment, hepatic IGFBP-3 gene expression increases in all the experimental groups, but in a more evident manner in the old group. With regard to the hepatic IGFBP-3 gene expression, the sensitivity to the same pharmacological dose of exogenous GH in the two groups with the same weight (middle-aged and old groups), that is the same dose per body weight, is even increased in the old group, since the percentage of the hepatic IGFBP-3 mRNA accumulation after exogenous $\mathrm{GH}$ is higher in this group.

The sensitivity to the induction of IGF-I gene expression by exogenous $\mathrm{GH}$ in extrahepatic tissues such as kidney and testis, two organs influenced by aging, is a matter of controversy and there are no well-established data in aging humans or rats (42-45). Our data indicate that in the kidney the sensitivity to the induction of IGF-I gene expression by exogenous $\mathrm{GH}$ in old male animals is not significantly different from the middle-aged rats, when both groups were receiving the same pharmacological dose of GH per body weight, although a tendency to decrease with age is suggested. In the kidney, IGF-I is mainly localized in collecting ducts. It increases after $\mathrm{GH}$ 


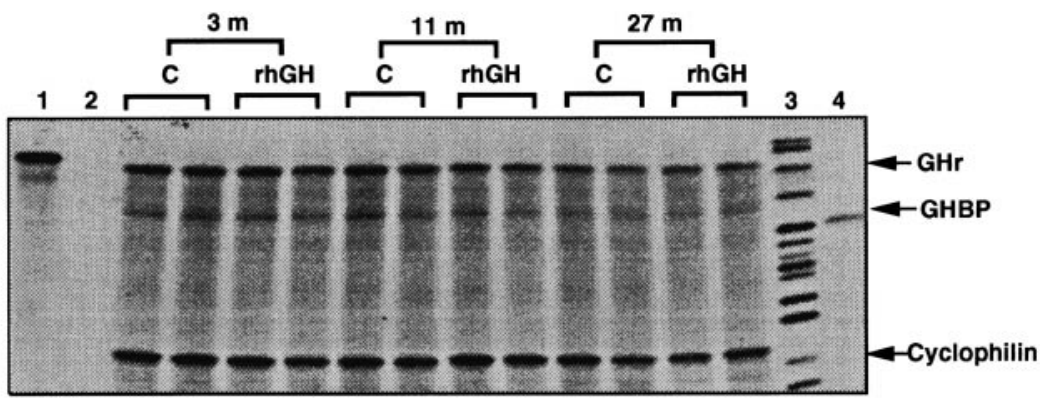

GHr

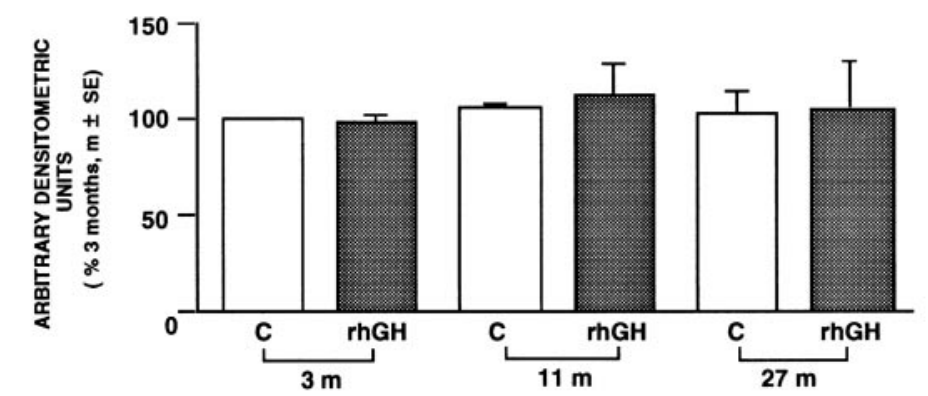

GHBP

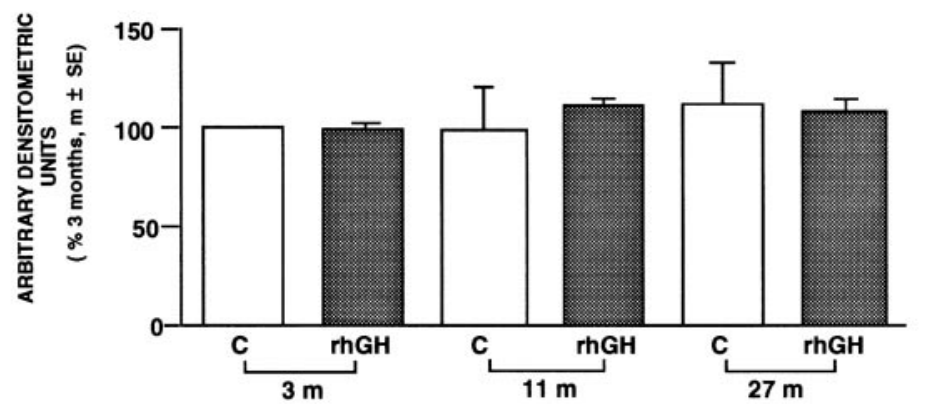

Figure $5 \mathrm{GHr}$ and GHBP expression in the kidney of young (3-month-old), middle-aged (11-month-old) and old (27-month-old) rats and the effect of rhGH treatment. Twenty micrograms of total kidney RNA were subjected to solution hybridization/RNase protection assay using the antisense $\mathrm{GHr}$ / GHBP and cyclophilin probes. The positions of each protected fragment are indicated on the right. After correction for cyclophilin levels, optical density units were adjusted so that the ratio obtained from kidneys of rats aged 3 months $(3 \mathrm{~m})$ equaled 100 . Lane 1 , undigested IGF-I probe. Lane 2, IGF-I and cyclophilin probes after RNase A and T1 digestion. Lane 3, molecular weight marker. Lane 4, undigested cyclophilin probe. Each lane represents a pool of three rats. Results are the mean \pm S.E. of three lanes. administration at this site, but not in other portions of the nephron (43). Local IGF-I gene expression might explain why we have not been able to detect significant agerelated changes in the mRNA when the whole kidney tissue was analyzed (42).

In the testis of the old group of rats, exogenous $\mathrm{GH}$ provokes a higher percentage increase of IGF-I mRNA accumulation than in the middle-aged or young group, with the same or higher dose of GH per body weight. These data indicate that the sensitivity of IGF-I gene induction by GH in the old testis is not affected by age. It has been suggested that IGF-I in the testis enhance the maturation and steroidogenic responsiveness to gonadotropins. Recent studies have shown the presence of GHr mRNA in purified progenitor, immature and adult Leydig cells of the rat, and the existence of a functional GH signaling pathway in these cells (44). These results are compatible with the modulatory effect of $\mathrm{GH}$ on testicular function, as suggested by the clinical situation in which puberty is delayed in the presence of $\mathrm{GH}$ deficiency $(45,46)$, and the responsiveness to gonadotropin is improved by $\mathrm{GH}$ treatment in humans with GH deficiency (45).

Our results also suggest that, in contrast to hepatic IGF-I, kidney and testis IGF-I gene expression is not so critically dependent on endogenous GH in normal conditions, as no decrease of IGF-I mRNA accumulation in these organs occurred in a physiological situation of lower GH gene expression and secretion that occurs with aging. However, when exogenous GH is administered to the rats in the conditions of the study, regarding the dose, the frequency and the route of administration, there is an evident increase of IGF-I mRNA accumulation in these organs. In other experimental situations of more marked GH deficiency such as hypophysectomy, exogenous $\mathrm{GH}$ was also able to induce IGF-I gene expression in these two organs, but the sensitivity was not specifically studied (39). This 

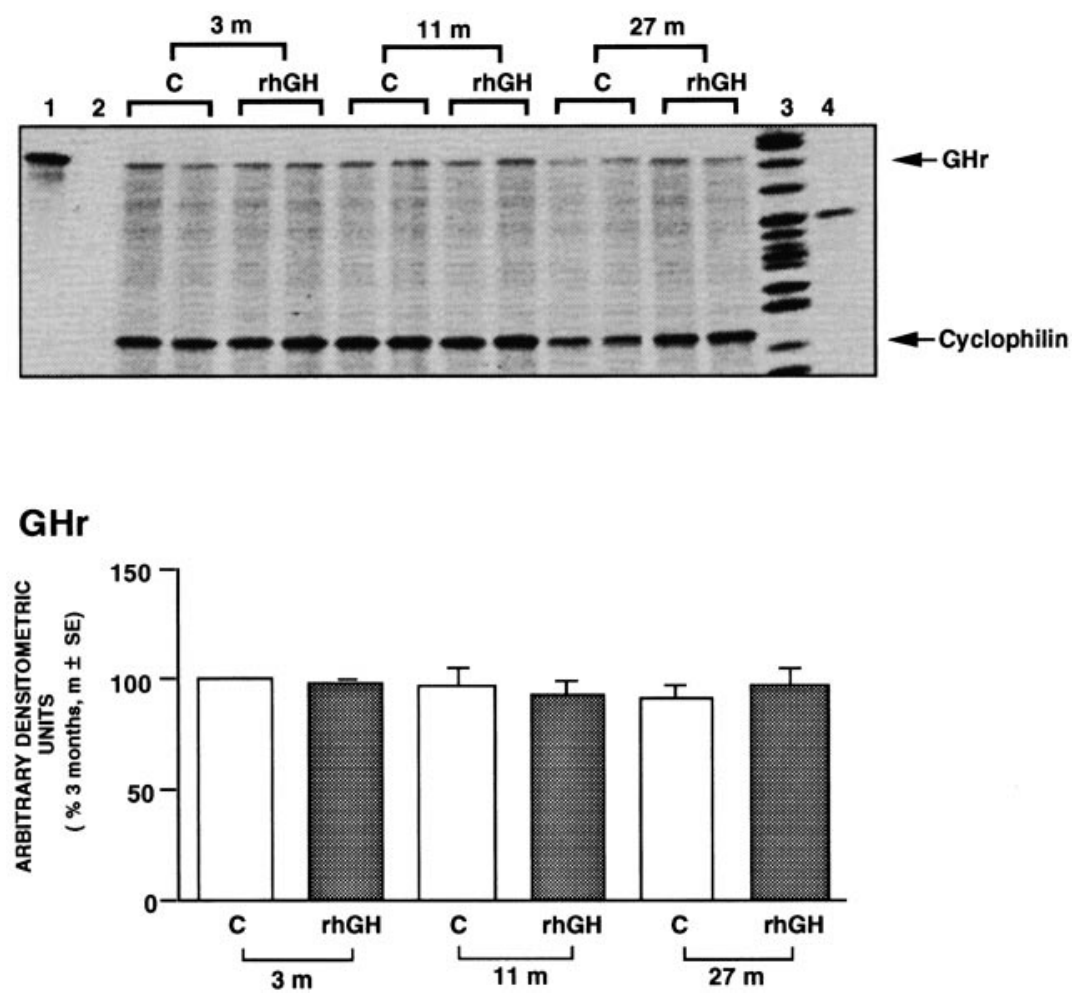

Figure $6 \mathrm{GHr}$ mRNA in the testis of young (3month-old), middle-aged (11-month-old) and old (27-month-old) rats and the effect of rhGH treatment. Twenty micrograms of total testis RNA were subjected to solution hybridization/ RNase protection assay using the antisense $\mathrm{GHr}$ probes. The positions of each protected fragment are indicated on the right. After correction for cyclophilin levels, optical density units were adjusted so that the ratio obtained from testis of rats aged 3 months $(3 \mathrm{~m})$ equaled 100. Lane 1, undigested IGF-I probe. Lane 2, IGF-I and cyclophilin probes after RNase A and T1 digestion. Lane 3, molecular weight marker. Lane 4, undigested cyclophilin probe. Each lane represents a pool of three rats. Results are the mean \pm S.E. of three lanes. action could be interpreted as pharmacological since this only occurs in the experimental situation of exogenous GH administration and not in the physiological condition of partial GH deficiency that takes place in aging.

The presence of similar values of GHr and GHBP mRNA accumulation in liver, kidney and testis in all the experimental groups suggests that the expression of this gene is not age dependent and not affected by GH treatment, at least in the tissues studied. According to our data, other studies have shown no changes in GHr and GHBP gene expression in hypophysectomized animals treated with exogenous GH and IGF-I $(34,47,48)$.

An important controversy exists with regard to the GHr or the GHBP in the tissues of aging animals and humans. In the liver of aging mice, more than a twofold increase in GHr binding capacity was found when compared with younger animals, with no difference in $K_{\mathrm{d}}$ by Scatchard analysis (31). Similar results have been described in young female rats (30) and in humans (32). However, in this study in Wistar male rats, no difference was shown in the basal mRNA accumulation in either one of the two transcriptional subspecies of the GHr gene and in either of the tissues studied, including liver, kidney and testis, in relation to age. In a similar manner, no modifications were produced in the levels of the two transcripts by repetitive or chronic exogenous GH administration. This part of the study is also in discordance with previous studies in humans showing that exogenous $\mathrm{GH}$ produced an acute decrease in circulating GHBP levels, independently of age (32). Post-transcriptional alterations of the receptor protein or its functionality, not assessed in this study, could explain those critical discrepancies.

The effect observed of exogenous rhGH administration on serum and pituitary IR-GH and the action on the accumulation of GH mRNA confirms previous studies showing that $\mathrm{GH}$ regulates its own secretion throughout a negative long-loop feedback mechanism inhibiting $\mathrm{GH}$ release and gene expression in the pituitary $(40,49)$. The relative sensitivity of this negative feedback action can be concluded from the fact that exogenous $\mathrm{GH}$ is given at the same dose per body weight in the middle-aged and old rats. In these experimental conditions the inhibitory effect of exogenous $\mathrm{GH}$ on the accumulation of $\mathrm{GH}$ mRNA is equally potent in the two groups. This is also suggested in the comparison with the young group of rats in which a lower effect was shown when the same dose was administered to animals of a lower weight. Therefore, data indicate the persistence of a normal longloop feedback function of $\mathrm{GH}$ in the pituitary of aging rats, but at a lower level because of the potential implication of hypothalamic secretagogues such us somatostatin and growth hormone-releasing factor (GRF).

This study indicates that the mechanism of the decreased IGF-I and IGFBP-3 gene expression that occurs with aging is due to the diminution of $\mathrm{GH}$ gene expression and $\mathrm{GH}$ secretion, and that the relative $\mathrm{GH}$ 

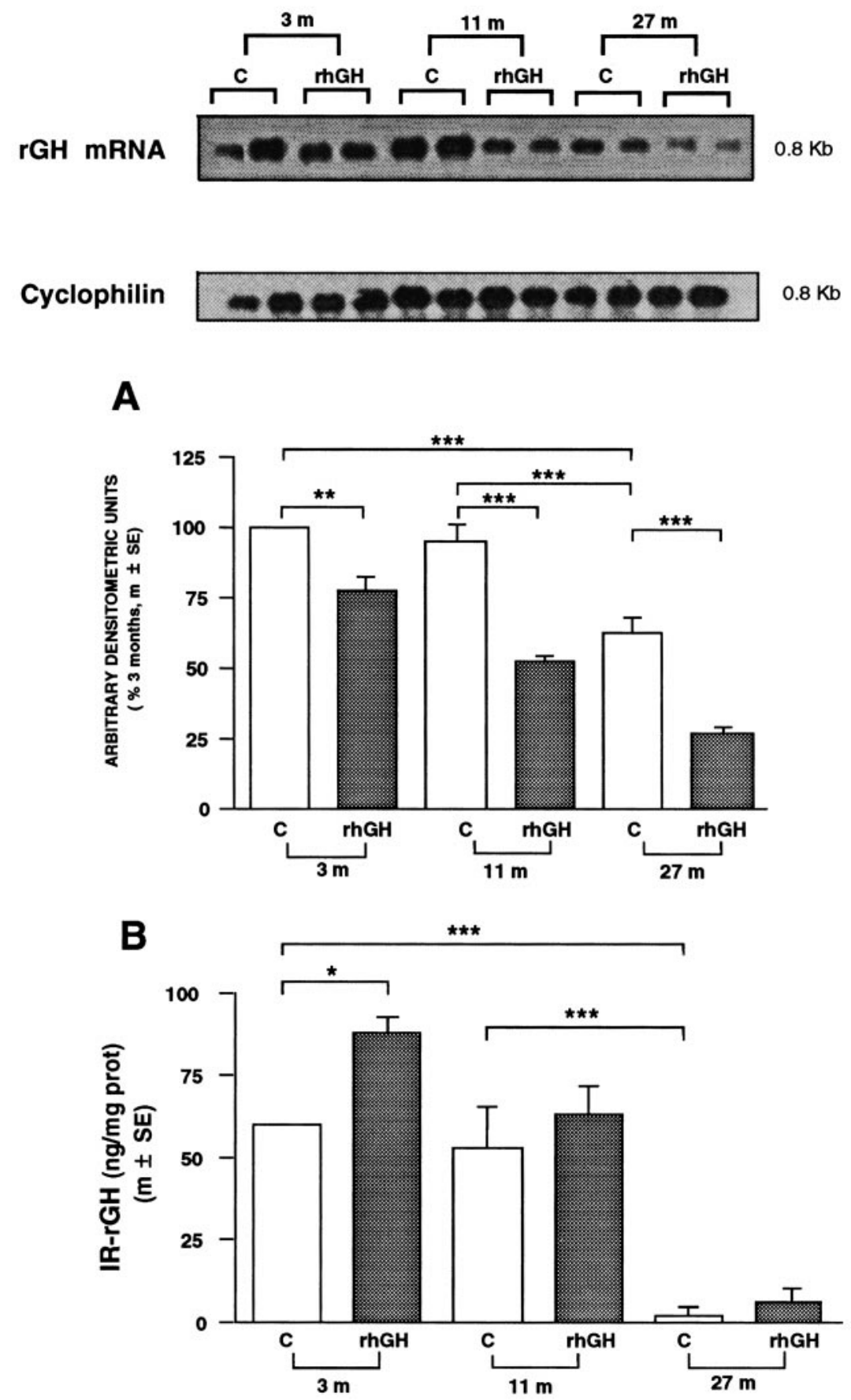

Figure 7 Pituitary GH gene expression and pituitary IR-GH content of young (3-monthold), middle-aged (11-month-old) and old (27-month-old) rats and the effect of rhGH treatment. $(A) \mathrm{GH}$ mRNA levels. Two micrograms of total pituitary RNA were subjected to Northern blot using the GH probe. After correction for cyclophilin levels, optical density units were adjusted so that the ratio obtained from pituitaries of rats aged 3 months $(3 \mathrm{~m})$ equaled 100.

Results are the mean \pm S.E. $(n=3)$. $(B)$ Pituitary IR-GH levels. Each lane represents a pool of three rats. Results are the mean \pm S.E. of three lanes. ${ }^{*} P<0.05$, ${ }^{* *} P<0.01$ and ${ }^{* * *} P<0.001$. deficiency of senescence and its consequences on body composition and effects on other extrahepatic tissues can be completely restored by repetitive exogenous $\mathrm{GH}$ administration. The study also suggests that there is no decreased sensitivity to exogenous rhGH in the liver, and extrahepatic tissues of aging male rats, in the conditions of the study. These conclusions give experimental support to the concept of an efficient $\mathrm{GH}$ substitution therapy for aging humans.

\section{Acknowledgements}

We thank Drs E. Hernández and D. LeRoith for providing the cDNAs necessary to generate the riboprobes. The rat GH kit was provided by the National Hormone and Pituitary Program/NIDDK. We also thank Purificación Mota Nieto for her technical assistance. This work was supported by grants 98/0343 and 99/0204 from FIS. 


\section{References}

1 Vermeulen A. Nyctohemeral growth hormone profiles in young and aged men: correlation with somatomedin-C levels. Journal of Clinical Endocrinology and Metabolism 198764 884-888.

2 Cuneo RC, Salomon F, McGauley GA \& Sönksen PH. The growth hormone deficiency syndrome in adults. Clinical Endocrinology 199237 387-397.

3 Corpas E, Harman M \& Blackman MR. Human growth hormone and human aging. Endocrine Reviews 199314 20-39.

4 Rudman D, Feller AG, Nagraj HS, Gergans GA, Lalitha PY, Goldberg AF et al. Effects of human growth hormone in men over 60 years old. New England Journal of Medicine 1990323 1-6.

5 De Boer H, Block G-J \& Van der Veen EA. Clinical aspects of growth hormone deficiency in adults. Endocrine Reviews 199516 63-86.

6 Johannsson G, Marin P, Lönn L, Ottosson M, Stenlöf K, Bjorntorp P et al. Growth hormone treatment of abdominally obese men reduces abdominal fat mass, improves glucose and lipoprotein metabolism and reduces diastolic blood pressure. Journal of Clinical Endocrinology and Metabolism 199782 727-734.

7 Jorgensen JOL, Perdensen SA, Thuesen L, Jorgensen J, Moller N, Müller J et al. Long-term growth hormone treatment in growth hormone deficient adults. Acta Endocrinologica 1991125 $449-453$.

8 Tannenbaum GS \& Martin JB. Evidence for an endogenous ultradian rhythm governing growth hormone secretion in the rat. Endocrinology 197698 562-568.

9 Sonntag WE, Steger RW, Frohman LJ \& Meites J. Decreased pulsatile release of growth hormone in old male rats. Endocrinology 1980107 1875-1879.

10 Velasco B, Cacicedo L, Escalada J, López-Fernández J \& Sánchez-Franco F. Growth hormone gene expression and secretion in aging rats is age dependent and not ageassociated weight increase related. Endocrinology 1998139 1314-1320.

11 Han V, D'Ercole A \& Lund P. Cellular localization of somatomedin (insulin-like growth factor) messenger RNA in the human fetus. Science 1987236 193-197.

12 Liu JL, Yakar S \& LeRoith D. Conditional knockout of mouse insulin-like growth factor-1 gene using Cre/loxP system. Proceedings of the Society for Experimental Biology and Medicine 2000223 344-351.

13 Sonntag WE, Lenham JE \& Ingram RL. Effects of aging and dietary restriction on tissue protein synthesis: relationship to plasma insulin-like growth factor-1. Journal of Gerontology 1992 47 B159-B163.

14 Sonntag WE, Hylka VW \& Meites J. Growth hormone restores protein synthesis in skeletal muscle of old male rats. Endocrinology 1984107 1875-1879.

15 Breese CR, Ingram RL \& Sonntag WE. Influence of age and longterm dietary restriction on plasma insulin-like growth factor I (IGF-I), IGF-I gene expression and IGF-I binding proteins. Journal of Gerontology 199146 B180-B187.

16 Roberts CT Jr, Lasky SR, Lowe WL Jr \& LeRoith D. Molecular cloning of rat insulin-like growth factor I complementary ribonucleic acids: differential messenger ribonucleic acid processing and regulation by growth hormone in extrahepatic tissues. Molecular Endocrinology 19871 243-248.

17 Roberts CT Jr, Brown AL, Graham DE, Seellg S, Berry S, Gabbay KH et al. Growth hormone regulates the abundance of insulin-like growth factor I mRNA in adult rat liver. Journal of Biological Chemistry 1986261 10025-10028.

18 Hynes MA, Van Wyk JJ, Brooks PJ, D’Ercole AJ, Jansen M \& Lund PK. Growth hormone dependence of somatomedin-C/insulin-like growth factor I and insulin-like growth factor II messenger ribonucleic acids. Molecular Endocrinology 19871 233-242.

19 Park GH \& Buetow DE. Genes for insulin-like growth factor I and II are expressed in senescent tissues. Gerontology 199137 $310-316$.
20 Möller C, Arner P, Sonnenfeld T \& Norstedt G. Quantitative comparison of insulin-like growth factor mRNA levels in human and rat tissues analyzed by solution hybridization assay. Journal of Molecular Endocrinology 19917 213-222.

21 Baxter R \& Martin JL. Structure of the Mr 140000 growth hormone-dependent insulin-like growth factor binding protein complex: determination by reconstitution and affinity-labeling. Biochemistry 198986 6898-6902.

22 Melián E, Velasco B, Barrios R \& Sánchez-Franco F. Basal and Growth hormone-induced hepatic messenger ribonucleic acid expression of insulin-like growth factor-I (IGF-I) and IGF-binding protein-3 is independent of hypersinsulinemia and increased energy status in the genetically obese Zucker rat. Endocrinology $19971381066-1071$.

23 Jansson JO, Eden S \& Isaksson O. Sexual dimorphism in the control of growth hormone secretion. Endocrine Reviews 19856 $128-150$.

24 Waters MJ, Barnard RT, Lobie PE, Lim L, Hamlin G, Spencer SA et al. Growth hormone receptors - their structure, localization and role. Acta Paediatrica Scandinavica 1990366 70-72.

25 Baumann G, Stolar MW, Amburn K, Barsano CP \& De Vries BC. A specific growth hormone-binding protein in human plasma: initial characterization. Journal of Clinical Endocrinology and Metabolism 198662 134-141.

26 Herington AC, Ymer S \& Stevenson J. Identification and characterization of a specific binding proteins for growth hormone in normal human sera. Journal of Clinical Investigation 198677 1817-1823.

27 Tzanela M, Wagner C \& Tannenbaum GS. Recombinant human growth hormone-binding protein fails to enhance the in vivo bioactivity of human growth hormone in normal rats. Endocrinology 1997138 5316-5324.

28 Ymer SI \& Herington AC. Evidence for the specific binding of growth hormone to a receptor-like protein in rabbit serum. Molecular and Cellular Endocrinology 198541 153-161.

29 Massa G, Mulumba N, Ketelslegers JM \& Maes M. Initial characterization and sexual dimorphism of serum growth hormone-binding protein in adult rats. Endocrinology 1990 126 1976-1980.

30 Takahashi S \& Meites J. GH binding to liver in young and old female rats: relation to somatomedin-C secretion. Proceedings of the Society for Experimental Biology and Medicine 1987186 $229-233$.

$31 \mathrm{Xu} \mathrm{X}$, Bennet SA, Ingram RL \& Sonntag WE. Decreases in growth hormone receptor signal transduction contribute to the decline in insulin-like growth factor I gene expression with age. Endocrinology 1995136 4551-4557.

32 Lieberman SA, Mitchell AM, Marcus R, Hintz RL \& Hoffman AR. The insulin-like growth factor I generation test: resistance to growth hormone with aging and estrogen replacement therapy. Hormone and Metabolism Research 199426 229-233.

33 Lowe WL Jr, Lasky SR, LeRoith D \& Roberts CT Jr. Distribution and regulation of rat insulin-like growth factor I messenger ribonucleic acids encoding alternative carboxyterminal E-peptides: evidence for differential processing and regulation in liver. Molecular Endocrinology 19882 528-535.

34 Domené H, Krishmanamurthi K, Eshet R, Gilad I, Laron Z, Koch I et al. Growth hormone $(\mathrm{GH})$ stimulates insulin-like growth factor-I (IGF-I) and IGF binding protein but not GH receptor gene in liver of juvenile rats. Endocrinology 1993133 675-682.

35 Seeburg PH, Shine J, Martial JA, Baxter JD \& Goodman HM. Nucleotide sequence and amplification in bacteria of structural gene for rat growth hormone. Nature 1977270 486-494.

36 Danielson PE, Forss-Peter S, Brow MA, Calavetta L, Douglas J, Milner RJ et al. p1B15: a cDNA clone of the rat mRNA encoding cyclophilin. DNA 19887 261-267.

37 Albiston AL \& Herington AC. Cloning and characterization of the growth hormone-dependent insulin-like growth factor binding protein 3 (IGFBP-3) in the rat. Biochemical and Biophysical Research Communications 1990166 892-897. 
38 Chomczynski P \& Sacchi N. Single-step method of RNA isolation by acid guanidinium thiocyanate-phenol-chloroform extraction. Analytical Biochemistry 1987162 156-159.

39 Gosteli-Peter MA, Winterhalter KH, Schmid C, Froesch R \& Zapf J. Expression and regulation of insulin-like growth factor I (IGF-I) and IGF-binding protein messenger ribonucleic acid levels in tissues of hypophysectomized rats infused with IGF-I and growth hormone. Endocrinology $19941352558-2567$.

40 López-Fernández J, Sánchez-Franco F, Velasco B, Tolon RM, Pazos F \& Cacicedo L. Growth hormone induces somatostatin and insulin-like growth factor I gene expression in the cerebral hemispheres of aging rats. Endocrinology $19961374384-4391$.

41 Maiter D, Underwood LE, Maes M, Davenport ML \& Ketelslegers J. Different effects of intermittent and continuous growth hormone (GH) administration on serum somatomedin-C/insulin-like growth factor I and liver $\mathrm{GH}$ receptors in hypophysectomized rats. Endocrinology 1988115 90-94.

42 Albiston AL \& Herington AC. Tissue distribution and regulation of insulin-like growth factor (IGF) binding protein-3 messenger ribonucleic acid (mRNA) in the rat: comparison with IGF-I mRNA expression. Endocrinology 1992130 497-502.

43 Lajara R, Rotwein P, Bortz JD, Hansen VA, Sadow JL, Betts CR et al. Dual regulation of insulin-like growth factor I expression during renal hypertrophy. American Journal of Physiology 1989 257 F252-F261.
44 Kanzaki M \& Morris PL. Growth hormone regulates steroidogenic acute regulatory protein expression and steroidogenesis in Leydig cell progenitors. Endocrinology 1999140 1681-1686.

45 Kulin HE, Samdjlike E, Santen R \& Santner S. The effects of GH on the Leydig cell response to chorionic gonadotropin in boys with hypopituitarism. Clinical Endocrinology 1981 45 463-472.

46 Rivalora MA, Heinrich JJ, Podesta FJ, Chondjnik MF \& Bergada C. Testicular function in hypopituitarism. Pediatric Research 19726 634-641.

47 Mathews LS, Enberg B \& Morstedt G. Regulation of rat growth hormone receptor gene expression. Journal of Biological Chemistry 1989264 9905-9910.

48 Maiter D, Jan LW, Adam E, Moats-Saats B, Mulumba N, Ketelslegers JM et al. Differential regulation by growth hormone (GH) of insulin-like growth factor I and GH receptor/binding protein gene expression in rat liver. Endocrinology 1992130 $3257-3264$.

49 Lanzi R \& Tannenbaum GS. Time course and mechanism of growth hormone's negative feedback effect on its own spontaneous release. Endocrinology 1992130 780-788.

Received 20 July 2000

Accepted 9 March 2001 